\title{
KELIMPAHAN ZOOPLANKTON DAN BIOMASSA IKAN TERI (Stolephorus spp.) PADA BAGAN DI PERAIRAN KWATISORE TELUK CENDERAWASIH PAPUA
}

\author{
Abundance of Zooplankton and Biomass of Anchovy (Stolephorus spp.) of Liftnet \\ at Kwatisore Bay, Cendrawasih Gulf, Papua
}

Oleh:

\author{
Amelian Dinisia ${ }^{1 *}$, Enan M. Adiwilaga ${ }^{2}$ Yonvitner $^{2}$ \\ ${ }^{1}$ Program Studi Pengelolaan Sumberdaya Perairan, Sekolah Pascasarjana, Institut Prtanian Bogor \\ 2 Departemen Manajemen Sumberdaya Perairan, Fakultas Perikanan dan Ilmu Kelautan, Institut Prtanian Bogor \\ *Korespondensi: amelian.ipb@gmail.com
}

Diterima: 07 Agustus 2015; Disetujui: 27 Oktober 2015

\begin{abstract}
Millions of organisms can be found in the Cenderawasih Gulf National Park area, especially in the waters of the Kwatisore Bay, Nabire and has been well-known to almost all over the world. Large zooplankton is an important food for migrated fish larvae and all kinds of fish including anchovies. Anchovy is the food of large and small pelagic fish groups. Groups of fish that use plankton as food were included anchovy. The main catch product of lift net at the Kwatisore bay is anchovy (Stolephorus spp.). This study aims to assess the level of availability of anchovy in relation to the abundance of zooplankton as food and to analyze the influence of anchovy fishing activities with lift net fishing gear. The results were obtained 51 species of zooplankton, which consists of 44 types holoplankton and 7 types of meroplankton. There were 17 species of zooplankton were found in the stomach of anchovy with the subgroup dominated by copepods (73.51\%). Among 17 species of zooplankton there 2 types that were found in all four sampling periods, namely Calanus sp. 2 and Euterpina acutifrons. There is a relationship between the abundance of individual zooplankton in the waters of the anchovy biomass and also between the abundance of zooplankton and biomass of anchovy.
\end{abstract}

Keywords: abundance of zooplankton, biomass of anchovy, lift net at Kwatisore

\section{ABSTRAK}

Jutaan organisme dapat ditemukan dalam kawasan Taman Nasional Teluk Cenderawasih khususnya di perairan Kwatisore, Nabire dan telah terkenal sampai hampir ke seluruh dunia. Zooplankton berukuran besar merupakan makanan penting bagi ikan-ikan yang bermigrasi dan larva semua jenis ikan termasuk didalamnya ikan teri. Ikan teri merupakan makanan dari kelompok ikan pelagis besar dan kecil. Kelompok ikan-ikan yang banyak memanfaatkan plankton dari kelompok ikan pelagis kecil diantaranya ikan teri. Hasil tangkapan utama bagan penangkap ikan pelagis kecil di perairan Kwatisore ialah jenis teri (Stolephorus sp.). Tujuan penelitian ini adalah untuk mengkaji tingkat ketersediaan ikan teri dalam kaitannya dengan kelimpahan zooplankton sebagai makanannya serta menganalisis pengaruh dari aktivitas penangkapan ikan teri dengan alat tangkap bagan. Secara keseluruhan dari seluruh stasiun dalam setiap periode sampling, diperoleh 51 jenis zooplankton yang terdiri atas 44 jenis holoplankton dan 7 jenis meroplankton. Terdapat 17 jenis zooplankton yang ditemukan dalam lambung ikan teri dengan didominasi oleh Sub-grup Copepoda (73,51\%). Diantara ke-17 jenis zooplankton tersebut terdapat 2 jenis yang ditemukan pada keempat periode sampling yaitu Calanus Sp.2 dan Euterpina acutifrons. Hasil 
analisis regresi linier antara biomassa ikan teri hasil tangkapan bagan dan kelimpahan maupun antara biomassa ikan teri hasil tangkapan bagan dan jumlah jenis zooplankton menunjukkan adanya korelasi positif.

Kata kunci: kelimpahan zooplankton, biomassa ikan teri, bagan di Kwatisore

\section{PENDAHULUAN}

Taman Nasional Teluk Cenderawasih (TNTC) yang terletak di pulau Papua adalah taman laut terluas di Indonesia, dengan luas kawasan 1.453.500 Ha yang ditetapkan dengan SK Menteri Kehutanan No 472/Kpts-II/1993 tanggal 2 September 1993 (Partono 2011). Kawasan TNTC secara administratif meliputi tiga kabupaten yaitu Kabupaten Manokwari dan Kabupaten Teluk Wondama di Propinsi Papua Barat serta Kabupaten Nabire di Propinsi Papua. Jutaan jenis organisme dapat ditemukan dalam kawasan Taman Nasional Teluk Cenderawasih khususnya di perairan Kwatisore, Nabire dan telah terkenal sampai hampir ke seluruh dunia.

Zooplankton adalah organisme plankton hewani dan bersifat heterotrofik, dimana untuk hidupnya membutuhkan materi organik dari organisme lainnya, khususnya fitoplankton (Wiadnyana dan Wagey 2004). Kaswadji et al. (1995), menyatakan bahwa fitoplankton merupakan awal dari model rantai makanan di lautan. Fitoplankton dimangsa oleh zooplankton dan kemudian akan dimangsa oleh ikan predator lainnya sehingga mengantarkan energi dan materi ke jenjang trofik yang lebih tinggi. Dalam mempelajari plankton dikenal istilah kelimpahan atau kepadatan yang dapat didefinisikan sebagai jumlah plankton per satuan volume air dan dapat dinyatakan dengan jumlah sel atau individu per $\mathrm{m}^{3}$ (Raymond 1963 dalam Erubun 2003). Zooplankton hanya dapat hidup dan berkembang dengan baik pada kondisi perairan yang sesuai. Pada perairan laut, faktor suhu dan salinitas dapat mempengaruhi struktur komunitas zooplankton. Kelimpahan dan komposisi zooplankton adalah faktor penting dalam mempelajari perairan tropis. Pengukuran ini biasanya digunakan dalam mempelajari produktifitas perairan (McLaren et al, 1979; Napp at al, 1996, dalam Sturdevant 2001).

Ikan teri merupakan salah satu ikan pelagis kecil yang memiliki sifat fototaksis positif. Bagan perahu tergolong ke dalam alat tangkap pasif yang dioperasikan pada malam hari dengan menggunakan cahaya lampu sebagai attractor dalam melakukan upaya penangkapan, dan untuk saat ini cukup efektif untuk menangkap ikan teri (Stolephorus spp.) (Kusuma 2000 dalam Ernaningsih 2008). Kondisi inipun dijumpai di perairan Kwatisore,
Nabire sesuai pernyataan Endrawati dan Irwani (2012) bahwa berdasarkan kepada kelimpahannya maka ikan teri (Stolephorus sp.) dijumpai pada semua periode sampling dan pada semua stasiun khususnya dengan alat tangkap lift-net atau bagan.

Biomassa merupakan parameter kunci untuk evaluasi keadaan stok ikan. Kajian tentang biomassa diperlukan untuk menghitung rekrutmen, sintasan dan pengaruh kegiatan perikanan serta faktor lingkungan. Parameter ini dapat mengalami perubahan dari waktu ke waktu (Thurow 1997). Menurut U.S Environmental Protection Agency (2002) pengukuran biomassa biasanya dimulai dengan memperkirakan ukuran populasi yang kemudian dikalikan dengan bobot rata-rata anggota populasi.

Hasil tangkapan utama bagan penangkap ikan pelagis kecil di perairan Kwatisore ialah ikan teri (Stolephorus sp.). Variasi hasil tangkapan teri selain disebabkan oleh faktor pencahayaan, dapat disebabkan oleh ketersediaan makanannnya dalam kolom perairan saat itu. Laevastu (1981) dalam Hayes et al (2007) menyatakan bahwa teri mempunyai pola pergerakan vertikal yang jelas, dimana pada siang hari berada di dasar perairan dan bermigrasi ke daerah dangkal dan berada di permukaan pada malam hari. Terdapat suatu dugaan bahwa migrasi vertikal teri pada malam hari bertujuan untuk mencari makan. Kondisi perairan yang terang karena pencahayaan bagan membantu teri dalam menangkap mangsanya. Sehingga pada bagan terjadi interaksi teri memakan zooplankton, sedangkan teri sendiri dimangsa oleh ikan-ikan yang lebih besar.

Keberadaan zooplankton sebagai makanan teri, diduga sebagai penentu keberadaan teri pada perairan Kwatisore. Dengan demikian kajian tentang kelimpahan zooplankton dengan biomassa ikan teri perlu untuk diteliti. Harapannya bahwa hasil kajian ini dapat dijadikan sebagai dasar dalam pengelolaan ekosistem perairan tersebut. Aktivitas penangkapan oleh nelayan secara kontinyu diduga dapat merubah struktur komunitas teri di perairan Kwatisore. Faktor yang diduga kuat berpengaruh terhadap penurunan hasil tangkapan yaitu: jenis dan jumlah alat tangkap, teknik penangkapan; distribusi, kelimpahan, potensi ikan, serta tingkat eksploitasi (pengelolaan) ikan teri, dan pencemaran (Sahubawa 2001). 
Penelitian ini bertujuan untuk mengkaji tingkat ketersediaan ikan teri dalam kaitannya dengan kelimpahan zooplankton sebagai makanannya serta menganalisis pengaruh dari aktivitas penangkapan ikan teri dengan alat tangkap bagan. Diharapkan hasil penelitian ini dapat bermanfaat sebagai informasi kepada seluruh lapisan masyarakat yang membutuhkan informasi tentang jenis serta kelimpahan zooplankton di perairan maupun dalam lambung ikan teri. Selain itu juga, dari hasl kajian ini dapat diperoleh informasi tentang biomassa ikan teri hasil tangkapan bagan di perairan Kwatisore Teluk Cenderawasih, Papua.

\section{METODE}

Penelitian ini dilakukan selama 4 bulan yakni bulan Juli hingga Oktober 2012, di Kawasan Teluk Cenderawasih khususnya di Perairan Kwatisore, Distrik Yaur, Kabupaten Nabire, Propinsi Papua (Gambar 1.) Pengambilan sampel pada 3 buah bagan penangkap teri sebagai titik stasiun pengamatan yang diharapkan akan dapat mewakili keseluruhan lokasi penelitian.

Alat dan bahan yang digunakan dalam penelitian ini adalah net Zooplankton dengan diameter mulut net $25 \mathrm{~cm}$, panjang badan net $60 \mathrm{~cm}$ dengan ukuran mata jaring $50 \mu \mathrm{m}$, botol sampel, ember, alat bedah, lugol, alkohol konsentrasi akhir 4\%, gelas ukur, aquades, botol sampel, Sedgwick Rafter Cell, pipet, mikroskop trinokuler dilengkapi kamera dan display monitor, GPS, thermometer, $\mathrm{pH}$ meter, refraktometer, DO meter, alat tulis-menulis, kamera.

Setelah dilakukan pengambilan sampel ikan teri maka kemudian dilakukan pembedahan dari bagian anus ke arah perut bagian atas untuk mengambil isi lambung. Selanjutnya isi lambung yang telah dikeluarkan diawetkan dalam alkohol $4 \%$ untuk menganalisis makanan dalam hal ini identifikasi zooplankton yang dimakan oleh ikan teri tersebut. Setelah diawetkan dengan lugol di lapangan dan dibawa ke laboratorium, sampel zooplankton kemudian diendapkan selama 24 jam untuk mengukur volume endapan, kemudian diencerkan 10 kali. Sub sampel diambil sebanyak $1 \mathrm{ml}$ dengan 2 kali ulangan lalu diamati di bawah mikroskop Trinokuler dengan pembesaran yang dibutuhkan.

Volume air tersaring dihitung menggunakan formula menurut Newell dan Newell (1977):

$$
V=\pi \cdot r^{2} \cdot 1
$$

Dimana, $\quad V=$ Volume air tersarin; $\pi=$ Nilai tetapan; $r=$ Jari-jari bagian depan mulut jaring; dan I = Jarak yang ditempuh oleh jaring selama penarikan.

Rumus penentuan kelimpahan plankton dengan rumus umum (Eaton et al. 1995) :

$$
N=\frac{C \times 100 \mathrm{~mm}^{\mathrm{s}}}{L \times D \times W \mathrm{~S}}
$$

Dimana, $\mathrm{N}=$ Kelimpahan plankton (ind $/ \mathrm{m}^{3}$ ); $\mathrm{C}=$ Jumlah Individu; $L=$ Panjang slide/strip (50 $\mathrm{mm}) ; \mathrm{D}=$ Kedalaman slide/strip $(10 \mathrm{~mm}) ; \mathrm{W}=$ Lebar slide/strip $(20 \mathrm{~mm}) ; \mathrm{S}=$ Jumlah strip yang diamati (1000 strip).

Sampel plankton yang telah dimampatkan dengan plankton net, maka rumus (2) dimodifikasi sebagai berikut :

$$
N=\frac{1}{A} x \frac{B}{C} x F p x n
$$

Dimana, $\mathrm{N}=$ Kelimpahan plankton (ind $\left./ \mathrm{m}^{3}\right) ; \mathrm{A}=$ Volume air yang disaring $\left(15,4056 \mathrm{~m}^{3}\right) ; \mathrm{B}=$ Volume air tersaring $(\mathrm{ml}) ; \mathrm{C}=$ Volume slide $(1$ $\mathrm{ml}) ; \mathrm{Fp}=$ Faktor pengenceran (10 kali); dan $\mathrm{n}=$ Jumlah individu (individu).

Indeks keanekaragaman dihitung berdasarkan rumus Shannon dan Wiener dalam Nugroho (2006) :

$$
\begin{aligned}
& H=-\sum_{1=1}^{s} P i \ln P i . \\
& P i=\frac{n i}{N} \ldots \ldots \ldots \ldots \ldots \ldots \ldots \ldots \ldots \ldots \ldots
\end{aligned}
$$

Dimana, $\mathrm{H}^{\prime}=$ Indeks Keanekaragaman; $\mathrm{Pi}=$ kelimpahan relatif dari jenis biota ke-i yang besarnya antara 0,0 dan 1,$0 ; \mathrm{ni}=$ jumlah individu jenis ke-i; $\mathrm{N}=$ jumlah total individu; $\mathrm{S}=$ jumlah jenis; dan $\Sigma=$ jumlah.

Nilai keseragaman diketahui melalui cara membandingkan indeks keanekaragaman dengan nilai maksimumnya, yang dihitung dengan rumus (Nugroho 2006):

$$
e=\left[\frac{H^{s}}{H^{\prime} \text { maks }}\right]
$$

Dimana, e (Eveness)= Indeks Keseragaman; $H^{\prime}=$ Indeks Keanekaragaman; $H^{\prime}$ Maks= In S; dan $S=$ jumlah jenis.

Menurut Romimohtarto dan Juwana (2001), nilai indeks dominasi (C) bertujuan untuk mengetahui ada atau tidak jenis yang mendominasi dalam suatu perairan.

$$
\mathrm{C}=1-\mathrm{e}
$$

Dimana, $\mathrm{C}=$ indeks dominasi; dan e = indeks Eveness (keseragaman jenis). 

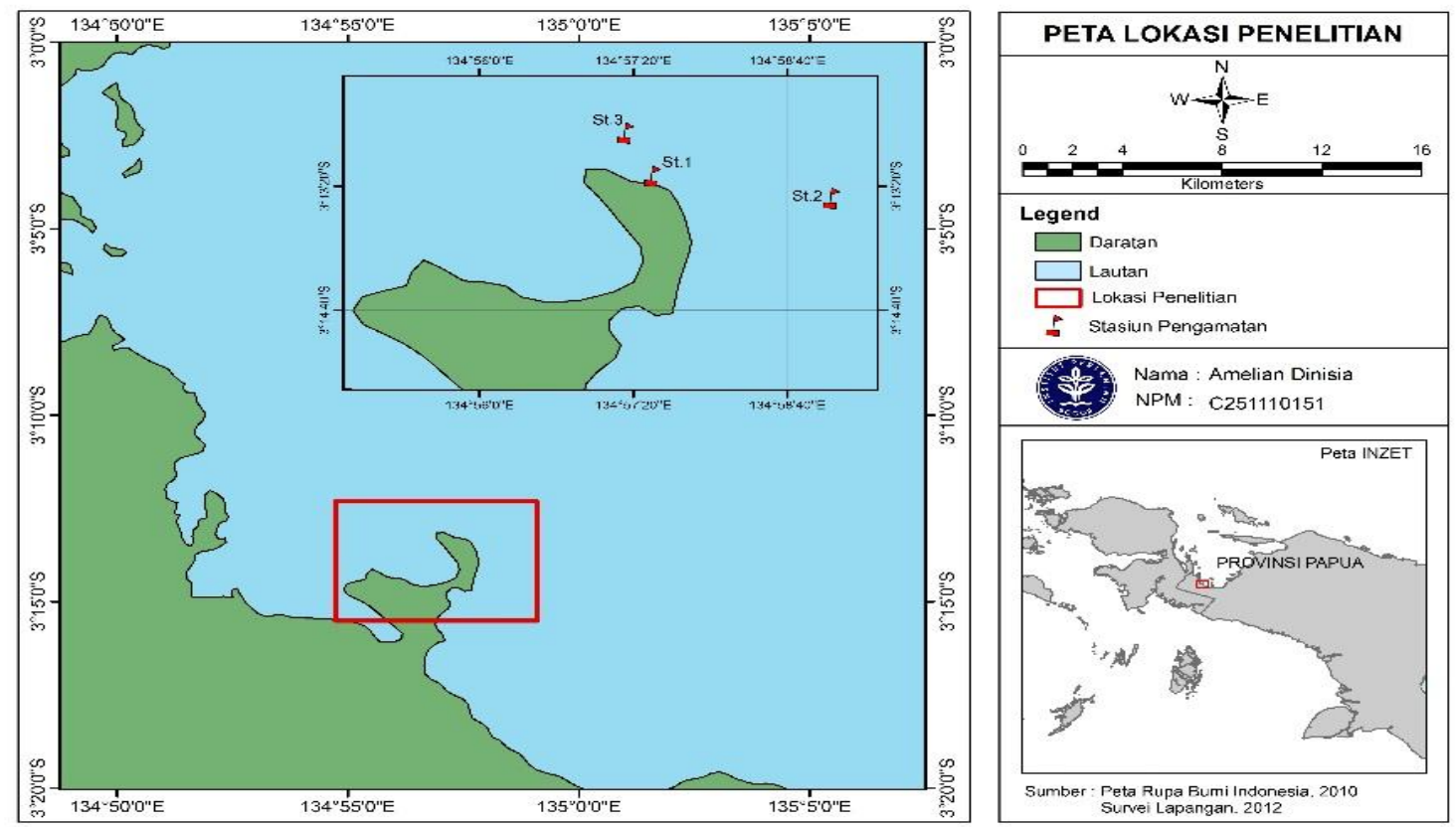

Gambar 1 Peta lokasi penelitian

Menurut Hayes et al. (2007), dalam situasi yang paling sederhana, biomassa ikan teri dihitung sebagai berikut:

$$
\widehat{B}=\widehat{N} \cdot \bar{w}
$$

$$
\begin{aligned}
& \hat{N}=\text { Kelimpahan ikan teri } \\
& \bar{w}=\text { Rata-rata berat ikan teri (gram) } \\
& \widehat{\widehat{B}}=\text { Biomassa }
\end{aligned}
$$

Kelimpahan jenis dominan zooplankton dalam lambung dikorelasikan dengan kelimpahan zooplankton sejenis diperairan. Analisis korelasi dilakukan dengan rumus (Walpole 1993).

$$
r=\frac{n \sum_{i=1}^{n} x_{i} y_{i}-\left(\sum_{i=1}^{n} x_{i}\right)\left(\sum_{i=1}^{n} y_{i}\right)}{\sqrt{\left[n \sum_{i=1}^{n} x_{i}^{2}-\left(\sum_{i=1}^{n} x_{i}\right)^{2}\left[n \sum_{i=1}^{n} y_{i}^{2}-\left(\sum_{i=1}^{n} y_{i}\right)^{2}\right]\right.}}
$$

$\mathrm{Y}=$ Kelimpahan jenis yang dominan dalam lambung.

$\mathrm{X}=$ Kelimpahan jenis yang sama dalam perairan.

Hubungan antara kelimpahan zooplankton dalam perairan dengan biomassa ikan teri hasil tangkapan bagan serta hubungan antara jumlah jenis zooplankton dalam perairan dengan biomassa ikan teri hasil tangkapan bagan dianalisis dengan analisis regresi sederhana menurut Walpole (1993) sebagai berikut :

$$
Y=\alpha+\beta X
$$

dimana, $Y=$ Biomassa ikan teri; $X=$ Kelimpahan zooplankton dalam perairan, atau Jumlah jenis zooplankton; $\alpha=$ Intersep; dan $\beta=$ slope.

\section{HASIL DAN PEMBAHASAN}

Suhu perairan dari hasil pengukuran di lapangan untuk ketiga stasiun pengamatan dan seluruh periode sampling memiliki nilai rata-rata $30,19{ }^{\circ} \mathrm{C}$ (Gambar 2) dengan nilai maksimum ditemukan pada stasiun 1 untuk bulan Oktober yakni $31,7^{\circ} \mathrm{C}$ dan nilai minimum pada stasiun 2 periode bulan September yaitu $29,5{ }^{\circ} \mathrm{C}$. Nilai tersebut masih termasuk suhu optimal yang dapat digunakan oleh zooplankton dan teri untuk pertumbuhan yaitu $29-30^{\circ} \mathrm{C}$. Hal ini juga sesuai dengan yang dikemukakan oleh Nugroho (2006) bahwa pada umumnya suhu optimal pada perkembiakan plankton adalah antara 29$30{ }^{\circ} \mathrm{C}$ tetapi pada umumnya jenis plankton dapat berkembang dengan baik pada suhu 25 ${ }^{\circ} \mathrm{C}$ atau lebih. Menurut Laevastu dan Hela (1970) dalam Sinaga (2009), pengaruh suhu terhadap ikan adalah dalam proses metabolisme, seperti pertumbuhan dan pengambilan makanan, aktivitas tubuh seperti kecepatan renang serta dalam rangsangan syaraf.

Faktor abiotik seperti salinitas (Ayad 2002 dalam Badsi et al. 2010) serta presipitasi dan kekeruhan telah didentifikasi sebagai faktor kritis dalam perkembangan zooplankton (Dejen et al. 2004 dalam Badsi 2010). Penulis lain (Wetzel, 2001; Fernandez-Rosado dan Lucena 2001; semuanya dalam Badsi 2010) juga mengatakan bahwa ada pengaruh interaksi faktor abiotik dan biotik dalam lingkungan yang 
berpengaruh terhadap komposisi, kelimpahan dan dinamika zooplankton. Salinitas selama penelitian memiliki rata-rata $36,75 \%$ o dengan nilai maksimum diperoleh pada stasiun 1 dan 2 periode bulan September yakni $42 \%$ dan nilai minimum diperoleh pada stasiun 1 periode bulan Oktober yakni 33\% (Gambar 3) sehingga dapat dikatakan bahwa salinitas perairan Perairan Kwatisore termasuk salinitas air campuran $(32-34 \%$ ) dan air samudera $(>34 \%$ ) karena perairan ini berhubungan langsung dengan perairan Samudera Pasifik di bagian Utara.

Nilai $\mathrm{pH}$ di lokasi penelitian untuk keseluruhan periode sampling memiliki rata-rata 7,52 dengan nilai maksimum ditemukan pada stasiun 1 periode bulan Agustus yaitu 7,94 dan nilai minimum ditemukan pada stasiun 1 periode bulan September yakni 6,96 (Gambar 4). Hasil penelitian ini sesuai dengan pernyataan Effendi (2003) bahwa sebagian besar biota akuatik sensitif terhadap perubahan $\mathrm{pH}$ dan menyukai nilai $\mathrm{pH}$ sekitar 7-8,5. Hal tersebut juga sejalan dengan pernyataan Omori dan lkeda (1984) dalam Nuraini (1997) bahwa di laut $\mathrm{pH}$ merupakan faktor pembatas bagi pertumbuhan plankton dan nilai $\mathrm{pH}$ optimum untuk bisa tumbuh dengan baik berkisar antara 7-8,5. Oksigen terlarut yang diperoleh di lapangan berkisar memiliki rata-rata $6,52 \mathrm{mg} / \mathrm{L}$ dengan nilai maksimum ditemukan pada stasiun 2 periode bulan Oktober yaitu $6,8 \mathrm{mg} / \mathrm{L}$ dan nilai minimum ditemukan pada stasiun 3 periode bulan September yakni 6,29 mg/L (Gambar 5). Konsentrasi DO di perairan ini berada di atas batas minimum untuk mendukung kehidupan di perairan seperti yang disebutkan oleh Prescot (1973) dalam Amiruddin (2006) yaitu sebesar 2,0 mg/L.

\section{Kelimpahan Zooplankton}

\section{Komposisi jenis dan kelimpahan zooplankton di peraian}

Secara keseluruhan dari seluruh stasiun dalam setiap periode sampling, diperoleh 51 jenis zooplankton yang terdiri atas 44 jenis holoplankton dan 7 jenis meroplankton yang masih lebih rendah bila dibandingkan dengan zooplankton yang ditemukan di perairan Teluk Baguala Ambon oleh Wenno dan Wenno (2011) yakni 73 jenis zooplankton yang terdiri atas 63 holoplankton dan 8 jenis meroplankton. Terdapat 8 jenis holoplankton yang selalu muncul pada setiap stasiun pengamatan dan setiap periode sampling yaitu Acartia Sp.1, Calanus sp.2, Oithona Sp., Oncaea venusta, Calanus Sp.1, Corycaeus Sp.2, Eucalanus sp.2, dan Euterpina acutifrons. Kedelapan jenis tersebut merupakan "grazer" atau pemakan fitoplankton dimana selanjutnya energi yang dihasilkan akan dimanfaatkan oleh organisme tingkatan diatasnya dalam hal ini adalah ikan teri. Copepoda yang ditemukan pada penelitian ini mencapai 58,82\% dari seluruh komunitas zooplankton di perairan Kwatisore, sesuai dengan pernyataan Wiadnyana (1996) bahwa kelompok copepoda dapat dianggap sebagai unsur yang dapat mewakili komunitas zooplankton karena kelompok tersebut sering mendominasi komunitas zooplankton pada berbagai perairan. Untuk meroplankton terdapat 1 jenis yang selalu muncul pada setiap stasiun dan periode sampling yaitu larva bivalvia, meski siklus hidup meroplankton neritik yang lebih pendek dalam bentuk planktonik namun larva bivalvia selalu muncul, sehingga diduga di perairan tersebut merupakan lingkungan yang baik untuk keberadaan sumberdaya bivalvia.

Jumlah jenis tertinggi ditemukan pada stasiun 1 periode bulan Juli yaitu 32 jenis dan terendah ditemukan pada stasiun 2 periode bulan September yakni 19 jenis (Gambar 6). Nilai kelimpahan individu tertinggi diperoleh pada stasiun 1 periode bulan Juli yaitu 12.035 $\mathrm{ind} / \mathrm{m}^{3}$ dan terendah pada stasiun 3 periode bulan September yakni $961 \mathrm{ind} / \mathrm{m}^{3}$. Hal ini terjadi karena pada akhir bulan Juli masih berada pada akhir musim timur memasuki musim Peralihan II dimana musim panas masih mendominasi dan curah hujan rendah sehingga juga turut mempengaruhi komposisi jenis dan kelimpahan zooplankton. Selain itu juga posisi stasiun 1 yang lebih dekat dengan daerah pantai bila dibandingkan dengan kedua stasiun lainnya mempengaruhi kelimpahan individu, mirip dengan yang dikemukakan oleh Young et al. (1996) bahwa biomassa zooplankton lebih tinggi ditemukan pada perairan dekat pantai, dalam hal ini perbandingan pada lokasi dekat pantai dan lepas pantai.

\section{Komposisi dan jumlah jenis zooplankton dalam lambung ikan teri}

Berdasarkan perhitungan frekuensi kehadiran terdapat 17 jenis zooplankton dengan didominasi oleh Sub-grup Copepoda (73,51\%) dan yang paling sedikit ditemukan adalah dari kelompok Crustacea lain dan Polychaeta yakni 0,54\% (Gambar 8). Pada ke 17 jenis zooplankton tersebut terdapat 2 jenis yang ditemukan pada keempat periode sampling yaitu Calanus sp.2 dan Euterpina acutifrons. Hasil penelitian ditemukan bahwa Calanus sp.2 terdapat melimpah di perairan dengan kemunculan pada keseluruhan stasiun pada setiap periode sampling, sedangkan Euterpina acutifrons meskipun ditemukan pada keseluruhan stasiun dan periode sampling namun tidak terdapat dalam jumlah yang melimpah dalam perairan. 


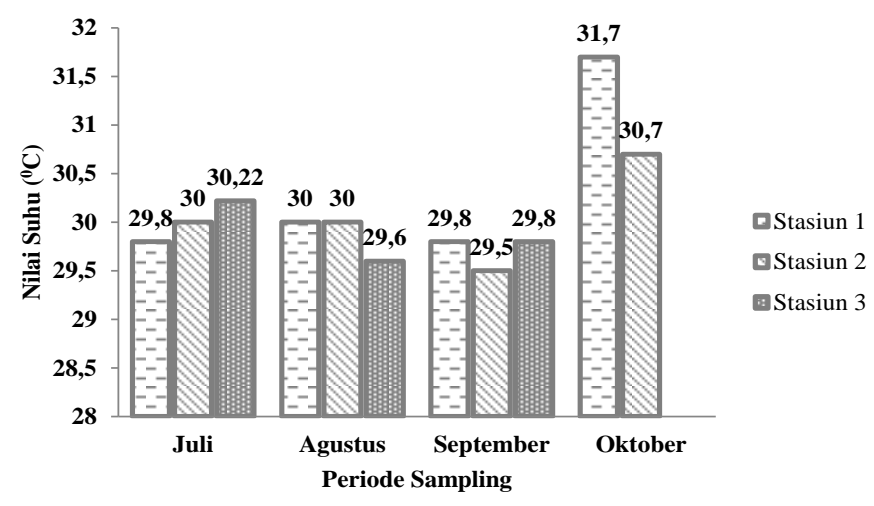

Gambar 2 Variasi suhu perairan pada lokasi penelitian untuk keseluruhan periode sampling

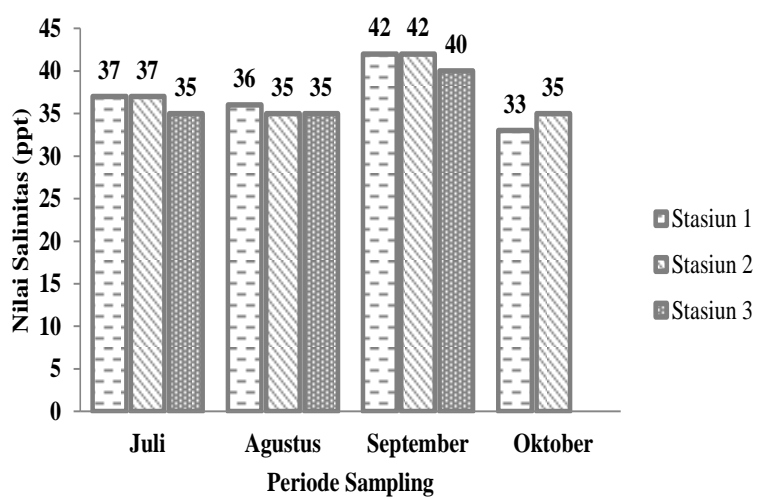

Gambar 3 Variasi salinitas perairan pada lokasi penelitian untuk keseluruhan periode sampling

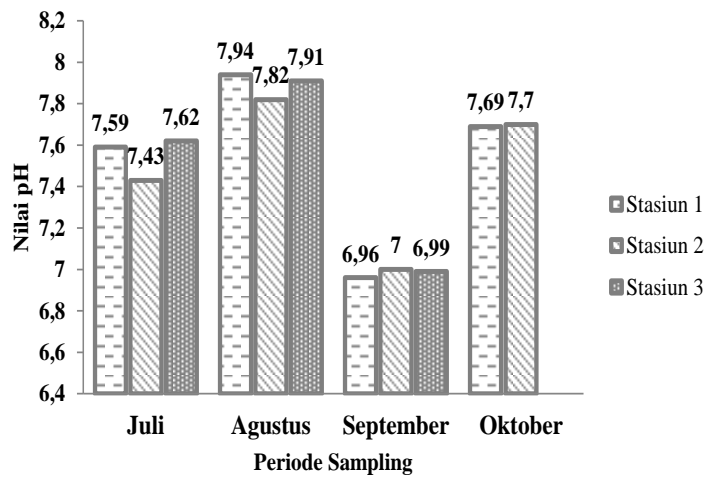

Gambar 4 Variasi pH perairan pada lokasi penelitian untuk keseluruhan periode sampling

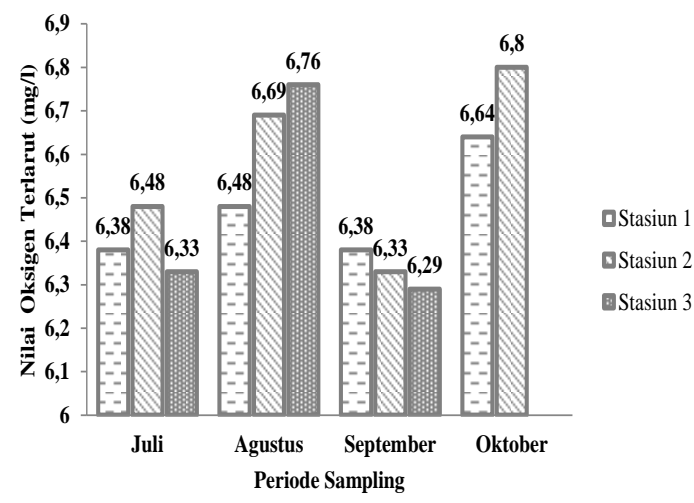

Gambar 5 Variasi oksigen terlarut perairan pada lokasi penelitian untuk keseluruhan periode sampling 


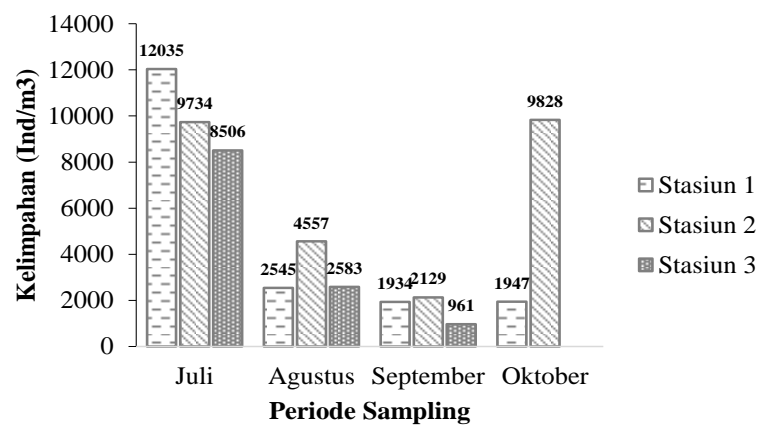

Gambar 6 Kelimpahan zooplankton dalam perairan pada lokasi penelitian untuk keseluruhan periode sampling

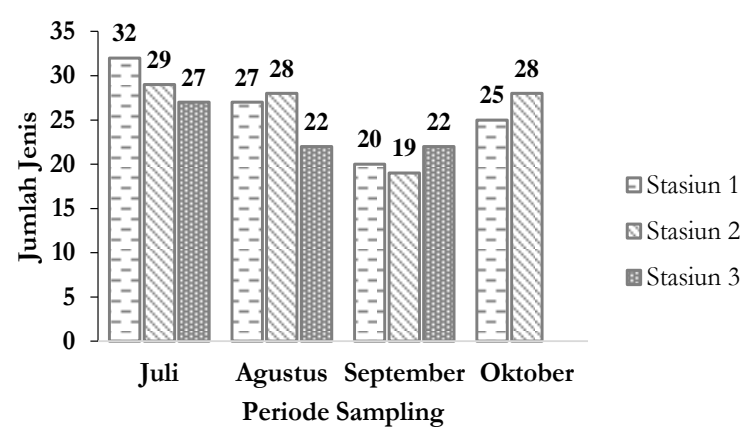

Gambar 7 Jumlah jenis zooplankton dalam perairan pada lokasi penelitian untuk keseluruhan periode sampling

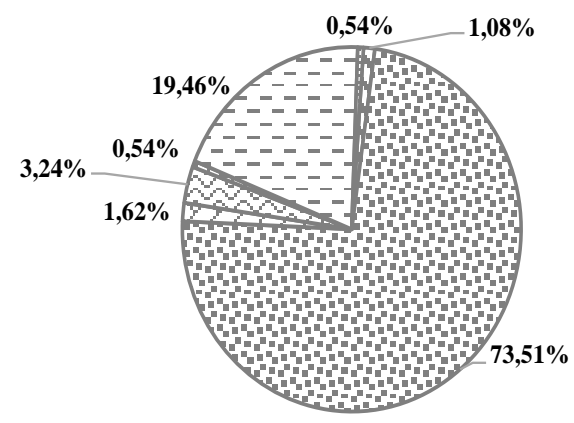

$\begin{array}{lll}\square \text { Heteropoda } & \square \text { Copepoda } & \square \text { Cladocera } \\ \square \text { Bivalvia } & \square \text { Polychaeta } & \square \text { Chaetognatha } \\ \square \text { Crustacea } & & \end{array}$

Gambar 8 Preferensi zooplankton dalam lambung ikan teri

Analisis korelasi antara kelimpahan jenis dominan zooplankton dalam lambung dengan kelimpahan zooplankton sejenis di perairan menghasilkan bahwa untuk copepoda jenis Calanus Sp.2 koefisien korelasi sebesar 0,36. Hal ini dapat diartikan bahwa melimpahnya Calanus sp.2 di perairan tidak mempengaruhi konsumsi ikan teri terhadap jenis tersebut. Lain halnya dengan Euterpina acutifrons, dihasilkan nilai koefisien korelasi sebesar 0,77 . Hal ini dapat diasumsikan bahwa melimpahnya jenis tersebut di perairan juga turut mempengaruhi tingkat konsumsi ikan teri terhadap jenis tersebut dan kecenderungan bahwa ikan teri menyukai satu jenis zooplankton tersebut.

\section{Indeks seleksi jenis makanan ikan teri}

Seleksi makan oleh ikan berarti preferensi atau menghindari komponen makanan tertentu yang tersedia di alam ( Berg 1979 dalam Duque dan Arcero 2003). Sedangkan James dan Findlay (1989) mengatakan bahwa ikan teri akan berubah dari penyaring makanan 
Tabel 1 Indeks seleksi isi lambung ikan teri yang ditemukan di Perairan Kwatisore

\begin{tabular}{clccc}
\hline No. & Jenis Zooplankton & $\begin{array}{c}\text { Total individu } \\
\text { dalam lambung }\end{array}$ & $\begin{array}{c}\text { Total individu } \\
\text { dalam perairan }\end{array}$ & $\begin{array}{c}\text { Indeks } \\
\text { Seleksi }\end{array}$ \\
\hline 1. & Acrocalanus gracilis & 1 & 1 & 1 \\
2. & Atlanta sp. & 1 & 4 & 0,25 \\
3. & Calanus sp.1 & 10 & 35 & 0,29 \\
4. & Calanus sp.2 & 60 & 92 & 0,65 \\
5. & Eucalanus sp. 1 & 1 & 11 & 0,09 \\
6. & Euterpina acutifrons & 48 & 15 & 3,20 \\
7. & Evadne sp. & 3 & 2 & 1,50 \\
8. & Larva Bivalvia & 6 & 17 & 0,35 \\
9. & Larva Echinodermata & 1 & 1 & 1 \\
10. & Larva Gastropoda & 1 & 6 & 0,17 \\
11. & Larva Polychaeta & 1 & 3 & 0,33 \\
12. & Lucicutia sp. & 2 & 1 & 2 \\
13. & Macrosetella gracilis & 1 & 2 & 0,50 \\
14. & Oithona sp. & 1 & 69 & 0,01 \\
15. & Oncaea venusta & 1 & 51 & 0,02 \\
16. & Sagitta sp. & 36 & 7 & 5,14 \\
17. & Scolecithrix danae & 11 & 6 & 1,83 \\
\hline
\end{tabular}

ke penggigit makanan karena adanya pengaruh ukuran makanan yang tersedia. Berdasarkan hasil yang diperoleh, terdapat 17 jenis zooplankton yang ditemukan didalam lambung ikan teri selama penelitian berlangsung. Indeks seleksi dari setiap jenis zooplankton yang dikonsumsi disajikan dalam Tabel 4.

Dari Tabel 1 diketahui bahwa indeks seleksi tertinggi adalah pada jenis Sagitta sp. dan diikuti oleh Euterpina acutifrons (Copepoda) sehingga dapat dikatakan bahwa jenis zooplankton tersebut merupakan zooplankton yang paling banyak atau paling disukai oleh ikan teri di perairan Kwatisore. Hal yang sama juga ditemukan oleh Duque dan Arcero, 2003. Kondisi ini menunjukan bahwa untuk menjamin ketersediaan ikan teri di perairan Kwatisore maka kondisi perairan harus tetap berada seperti saat penelitian berlangsung. Baum dan Worm (2009) mengatakan bahwa bila terjadi perubahan dalam jejaring makanan, maka akan ada komponen biotik dalam ekosistem yang hilang entah dari sisi pemangsa ataupun yang dimangsa.

\section{Indeks keanekaragaman, indeks keseragaman dan indeks dominasi}

Indeks keanekaragaman $\left(\mathrm{H}^{\prime}\right)$ pada lokasi penelitian adalah 2,33 yang menggambarkan bahwa keanekaragaman jenis sedang atau stabilitas komunitas zooplankton pada lokasi penelitian secara keseluruhan dalam kondisi sedang. Nilai rata-rata indeks keseragaman (e) pada perairan Teluk Kwatisore yaitu 0,72 dimana indeks ini mendekati 1 yang berarti keseragaman antar jenis dalam komunitas zooplankton di lokasi penelitian dapat dikatakan merata atau perbedaannya tidak menyolok. Hal ini mencerminkan bahwa kekayaan individu yang dimiliki oleh masing-masing jenis pada lokasi penelitian tidak jauh berbeda. Indeks dominasi pada lokasi penelitian yang rendah yakni 0,28 yang mendekati 0 menunjukkan bahwa tidak ada jenis zooplankton baik holoplankton maupun meroplankton tertentu yang mendominasi komunitas zooplankton yang ada di perairan Kwatisore. Kondisi ini menunjukkan bahwa kondisi komunitas relatif stabil.

\section{Biomassa ikan teri hasil tangkapan bagan}

Nilai biomassa ikan teri hasil tangkapan bagan, dihitung dari kelimpahan ikan teri sebagai hasil produksi tangkapan bagan yang dikalikan dengan rata-rata berat ikan teri $(2,33$ gram). Grafik nilai biomassa ikan teri untuk keseluruhan stasiun pengamatan dan periode sampling dapat dilihat pada Gambar 9. Total biomassa ikan teri tertinggi pada stasiun 1 dan 2 untuk keseluruhan periode sampling sedangkan total biomassa yang terendah terdapat pada stasiun 3. Hal tersebut diduga karena lebih dekatnya stasiun 1 dan 2 dengan pesisir pulau besar sehingga perairannya relatif lebih kaya akan bahan organik sehingga kelimpahan 
produsen primer dalam hal ini fitoplankton yang merupakan makanan zooplankton juga melimpah. Dengan demikian hasil tangkapan teri oleh bagan diduga sangat dipengaruhi oleh faktor kelimpahan produsen primer. Hal ini sesuai dengan pernyataan Cury et al. 2000 bahwa ketersediaan pakan serta proses fisika dalam perairan sangat berperan penting dalam kehidupan larva yang akhirnya berpengaruh terhadap kelimpahan ikan. Hunter dan Thomas, (1974) serta Lasker (1975) dalam Sameoto (1984) menemukan bahwa kelimpahan ikan teri (anchovy) sangat tergantung pada jumlah makanan yang melimpah.

\section{Hubungan Biomassa Ikan Teri dan Kelimpahan serta Jumlah Jenis Zooplankton di Perairan}

Hasil analisis regresi linier antara biomassa ikan teri hasil tangkapan bagan dan kelimpahan zooplankton di perairan Kwatisore menunjukkan adanya korelasi positif dengan koefisien determinasi 0,2739 (Gambar 10). Hal ini dapat diartikan bahwa kenaikan kelimpahan zooplankton di perairan berarti juga menunjukkan semakin banyak biomassa ikan teri yang tertangkap oleh bagan. Ketersediaan zooplankton memberi kontribusi sebanyak $27 \%$ $\left(R^{2}=0,27\right)$ terhadap keberadaan ikan teri di perairan, yang selanjutnya berpengaruh terhadap jumlah tangkapan. Hal ini berarti bahwa selain sumber makanan (zooplankton), ada faktor lain yang turut mempengaruhi jumlah tangkapan teri, dengan kontribusi $73 \%$. Faktorfaktor yang dimaksud, seperti kondisi fisik-kimia perairan, dan faktor teknis operasi penangkapan (Tupamahu \& Baskoro 2004 dalam Simbolon dkk. 2010), serta sifat fototaksis positif ikan teri (Iskandar et al. 2001 dalam Simbolon dkk. 2010). Berdasarkan hasil analisis, maka persamaan regresinya dapat dituliskan sebagai berikut:

$$
Y=0,0209 X+199,51
$$

Nilai konstanta sebesar 199,51, menunjukkan bahwa pada kondisi kelimpahan individu (X) bernilai nol, maka jumlah biomassa ikan teri akan bernilai positif, yaitu sebesar 199,51, sedangkan nilai koefisien regresi variabel $X$ (kelimpahan individu) bernilai 0,0209. Artinya jika kelimpahan individu bertambah sebesar satu satuan, maka jumlah biomassa ikan teri akan mengalami peningkatan sebesar 0,0209 satuan. Koefisien regresi $X$ bernilai positif berarti menunjukan terdapat hubungan positif antara jumlah biomassa ikan teri dengan kelimpahan individu, semakin bertambah jumlah kelimpahan individu maka jumlah biomassa ikan teri akan semakin meningkat.
Perhitungan biomassa ikan teri hasil tangkapan bagan dan jumlah jenis zooplankton dalam perairan juga menunjukkan adanya korelasi positif antara kedua variabel tersebut. Dimana diperoleh nilai koefisien determinasi sebesar 0,4031 (Gambar 11). Hal ini dapat diartikan juga bahwa kenaikan jumlah jenis zooplankton dalam perairan juga diikuti oleh kenaikan biomassa ikan teri hasil tangkapan bagan yang ada di perairan Kwatisore, Nabire. Berdasarkan hasil analisis maka persamaan regresinya dapat dituliskan sebagai berikut:

$$
Y=24,852 X-323,2
$$

Nilai konstanta sebesar -323,2, menunjukan bahwa pada kondisi kelimpahan individu (X) bernilai nol, maka jumlah biomassa ikan teri akan bernilai negatif, yaitu sebesar -323,2, sedangkan nilai koefisien regresi variabel $X$ (kelimpahan individu) bernilai 24,852. Artinya bahwa jika kelimpahan individu bertambah sebesar satu satuan, maka jumlah biomassa ikan teri akan mengalami peningkatan sebesar 24,852 satuan. Koefisien regresi $X$ bernilai positif berarti menunjukan terdapat hubungan positif antara jumlah biomassa ikan teri dengan kelimpahan individu, semakin bertambah jumlah kelimpahan individu maka jumlah biomassa ikan teri akan semakin meningkat.

Dengan demikian, keberadaan plankton di perairan perlu dijaga. Apabila keberadaan zooplankton sebagai makanan ikan teri terjaga maka keberadaan ikan teri sebagai sumberdaya perikanan yang cukup penting sebagai hasil tangkapan masyarakat Nabire dan juga sebagai makanan dari organisme yang lebih besar pada tingkat trofik berikutnya juga ikut terjaga.

\section{KESIMPULAN}

Secara keseluruhan diperoleh 51 jenis zooplankton yang terdiri atas 44 jenis holoplankton dan 7 jenis meroplankton. Terdapat 17 jenis zooplankton yang ditemukan dalam lambung ikan teri dengan didominasi oleh Subgrup Copepoda (73,51\%). Pada ke 17 jenis zooplankton tersebut terdapat 2 jenis yang ditemukan pada keempat periode sampling yaitu Calanus sp.2 dan Euterpina acutifrons. Indeks keanekaragaman $\left(H^{\prime}=2,33\right)$, Indeks Keseragaman $(e=0,72)$ dan Indeks dominasi $(C=0,28)$ menunjukkan keseragaman jenis zooplankton sedang/stabilitas komunitas sedang, keseragaman antar jenis merata dan tidak ada jenis tertentu yang mendominasi komunitas. Hasil analisis regresi linier antara biomassa ikan teri hasil tangkapan bagan dan kelimpahan maupun antara biomassa ikan teri 


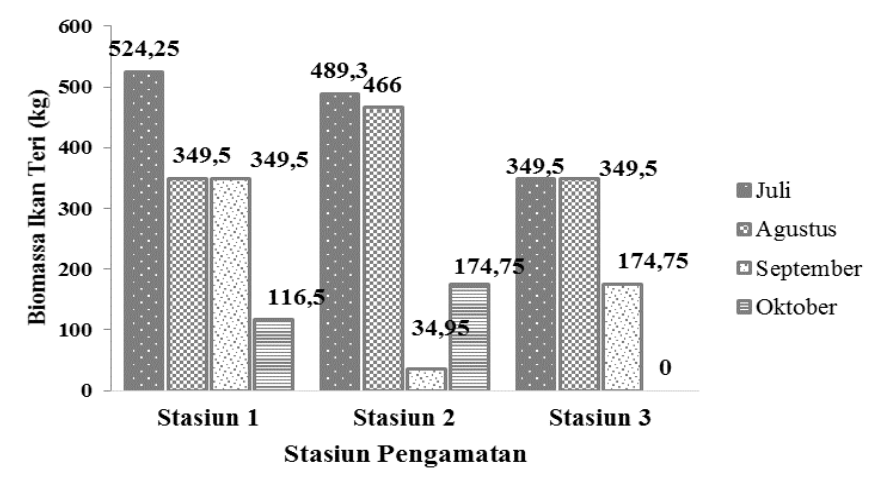

Gambar 9 Nilai biomassa ikan teri dan kelimpahan serta jumlah jenis zooplankton di perairan

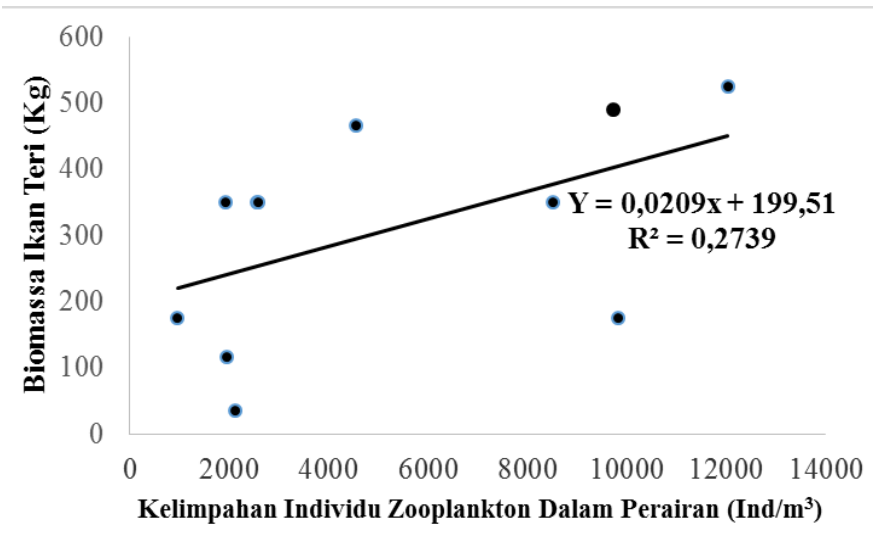

Gambar 10 Persamaan antara biomassa ikan teri dan kelimpahan zooplankton dalam perairan

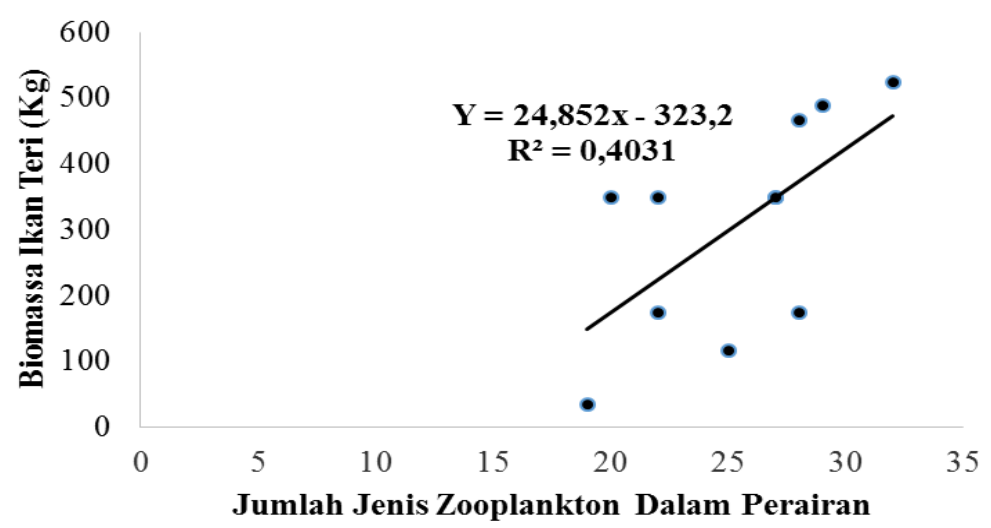

Gambar 11 Persamaan antara biomassa ikan teri dengan jumlah jenis zooplankton dalam perairan

hasil tangkapan bagan dan jumlah jenis zooplankton menunjukkan adanya korelasi positif, hal ini menunjukkan bahwa tingkat ketersediaan ikan teri terdapat korelasi dengan kelimpahan zooplankton.

\section{SARAN}

Berdasarkan hasil penelitian maka saran yang dapat diberikan adalah pemanfaatan harus memperhatikan tingkat kebutuhan makanan teri dan proses pembentukan biomassa, karena ada keterkaitan dalam struktur fungsi yang harus didalami pada penelitian selanjutnya.

\section{DAFTAR PUSTAKA}

Amiruddin. 2006. Interaksi Predasi Teri (Stolephorus spp.) selama Proses Penangkapan Ikan dengan Bagan Rambo: Hubungannya dengan Kelimpahan Plankton [tesis]. Bogor: Institut Pertanian Bogor. 
Badsi, H, Oulad RA, Loudiki, M, El Hafa M, Chakli, R, Aamiri A. 2010. Ecological factors affecting the distribution of zooplankton community in the Massa Lagoon (Southern Morocco). African Journal of Environmental Science and Technology. 4(11): 751-762.

Baum JK, Worm B. 2009. Cascading top-down effects of changing oceanic predator abundances. Journal of Animal Ecology. 699-714.

Cury P, Andrew B, Robert JMC, Astrid J, Renato AQ, Lynne JS, Hans MV. 2000. Small pelagics in upwelling systems: patterns of interaction and structural changes in "wasp-waist"ecosystems. ICES Journal of Marine Science, 57: 603-618.

Duque, G, Arcero AP. 2003. Feeding Selectivity Of Anchovia Clupeoides (Pisces: Engraulidae) In The Clenaga Grande De Santa Marta, Colombian Caribbean. Gulf and Caribbean Research. 15: 21-26.

Eaton, AD, Clesceri LS, Greenberg AE. 1995. Standard Methods for the Examination of Water and Wastewater. Washington DC: American Public Health Association.

Effendi H. 2003. Telaah Kualitas Air: Bagi Pengelolaan Sumber Daya dan Lingkungan Perairan. Kanisius.

Endrawati H, Irwani. 2012. Komposisi dan Kelimpahan Ichtyofauna di Perairan Morosari, Kecamatan Sayung, Kabupaten Demak. Buletin Oseanografi Marina. 1: 34-40.

Ernaningsih D. 2008. Analisis Usaha Penangkapan Ikan Teri dengan Bagan Perahu di Teluk Jakarta. Jurnal IImiah Satya Negara Indonesia. 1(2): 22-26.

Erubun I. 2003. Komposisi dan Kepadatan Fitoplankton di Perairan Teluk Ambon. [skripsi]. Ambon: Fakultas Perikanan dan Ilmu Kelautan. Universitas Pattimura.

Hayes DB, Bence JR, Kwak TJ, Thompson BE. 2007. Abundance, Biomass, and Production Estimation. Hal 327-374. Di dalam: Guy CS, Brown ML, editors. Analysis and interpretation of freshwater fisheries data; Maryland, Amerika Serikat. Maryland: American Fisheries Society.

James, AG., KP Findlay. 1989. Effect of particle size and concentration on feeding behaviour, selectivity and rates of food ingestion by the Cape anchovy Engraulis capensis. Marine Ecology Progress Series. 50: 275-294

Kaswadji RF, A Chaeruddin, Y Naulita, M.N.M. Natih. 1995. Dinamika fitoplankton permukaan di Teluk Pelabuhan Ratu dan kaitannya dengan rantai makanan di laut dan musim ikan. Laporan Penelitian. Bogor. Fakultas Perikanan, Institut Pertanian Bogor. 25 hal.

Newell GE, Newell RC. 1977. Marine Plankton. London: Hutchinson and Co. Ltd.

Nugroho A. 2006. Bioindikator Kualitas Air. Jakarta: Universitas Trisakti.

Nuraini RAT. 1997. Kepekaan Komunitas Zooplankton Terhadap Ketersediaan Bahan Organik dan Kelimpahan Fitoplankton di Tambak Bersubstrat Pasir. [tesis]. Bogor: Institut Pertanian Bogor.

Partono S. 2011. Kebijakan Pengelolaan Kawasan Konservasi. Makalah Disampaikan pada Workshop dan Training Pemantauan Whale Shark di TN Teluk Cenderawasih, Nabire. Jakarta: Ditjen PHKA Kementrian Kehutanan

Romimohtarto K, Juwana S. 2001. Biologi Laut: IImu Pengetahuan Tentang Biota Laut. Jakarta: Djambatan.

Sahubawa L. 2001. Dampak Pembuangan Limbah Terhadap Perubahan Kualitas Oseanografi Biofisik-Kimia Dan Produksi Ikan Teri (Stolephorus Spp.) di Perairan Laut Teluk Ambon. Jurnal Manusia dan Lingkungan 8(1): 15-29.

Sameoto DD. 1984. Environmental factors influencing diurnal distribution of zooplankton and ichthyoplankton. Journal of Plankton Research. 6(5).

Simbolon D, MFA Sondita, Amiruddin. 2010. Komposisi Isi Saluran Pencernaan Ikan Teri (Stolephorus Spp.) di Perairan Barru, Selat Makassar. Jurnal IImu Kelautan. 15(1): 7-16.

Sinaga MP. 2009. Analisis Hasil Tangkapan Pukat Ikan Kaitannya dengan Kandungan Klorofil-A dan Suhu Permukaan Laut di Perairan Tapanuli Tengah [thesis]. Bogor: Institut Pertanian Bogor.

Sturdevant MV. 2001. Summer Zooplankton Abundance and Composition Estimates from 20-m Vertical Hauls in Prince William Sound, Alaska, Using Three Net Mesh. Alaska Fishery Reasearch Bulletin. 8(2): 96-106. 
Thurow F. 1997. Estimation of the total fish biomass in the Baltic Sea during the 20th century. ICES Journal of Marine Science. 54: 444-461.

U.S. Environmental Protection Agency. 2002. Draft Final Ver II Fish Biomass Estimate for Housatonic River Primary Study Area. Environmental Remediation Contract General Electric (GE)/Housatonic River Project Pittsfield, Massachusetts Contract No. 33-94-D-0009/032.

Walpole RE. 1993. Pengantar Statistika. Edisi 3. Jakarta: PT. Gramedia Pustaka Utama

Wenno Y, AD Wenno. 2011. Hubungan antara beberapa faktor lingkungan Dengan kelimpahan zooplankton di perairan Teluk Baguala, Ambon. Jurnal Perikanan dan Kelautan. 7(2).

Wiadnyana NN, Wagey GA. 2004. Plankton, Produktivitas dan Ekosistem Perairan. DKP dan LIPI. Jakarta.

Wiadnyana NN. 1996. Kondisi Plankton di Perairan Sekitar Pulau Biak dan Teluk Cenderawasih, Irian Jaya. Buletin IImu Kelautan TORANI. 6(2).

Young JW, Bradford RW, Lamb TD, Lyne VD. 1996. Biomass of zooplankton and micronecton in the southern bluefin tuna fishing ground off eastern Tasmania, Australia. Marine Ecology Progress Series, 138: 1-14. 